\title{
Effects of Field Trypanosomosis on Blood Glucose and Urea Nitrogen Levels in Three Cattle Herds in Oyo State, Nigeria
}

\author{
Oladipo, T.A ${ }^{\mathbf{1}^{*}}$, Lasisi, O.T ${ }^{\mathbf{2}}$, Ijadunola T.I ${ }^{\mathbf{1}}$, Balogun F.A ${ }^{\mathbf{1}}$ \\ ${ }^{I}$ Federal College of Animal Health and Production Technology, Moor Plantation Ibadan \\ ${ }^{2}$ Department of Veterinary Medicine, University of Ibadan, Ibadan
}

*Corresponding Author: Oladipo, T.A, Federal College of Animal Health and Production Technology, Moor Plantation Ibadan.

\begin{abstract}
White Fulani, Sokoto Gudali, Red Bororo, Azawoak, Red Bororo Crosses and Sokoto Gudali Crosses, to evaluate the effect of natural bovine trypanosomosis on the blood urea nitrogen and blood glucose levels in three herds in Oyo state.

Jugular venipuncture, mid-coccygeal venipuncture and lateral saphenous venipuncture were used to obtain sample from live animals.

The blood glucose level was determined using glucometer with test kit strip while blood urea nitrogen was determined in the laboratory using BUN kit.

A White Fulani breed of cattle is the most common breed in Nigeria. Animals infected with trypanosomes had low blood glucose and blood urea nitrogen. White fulani cattle breed was said to be more susceptible to trypanosomosis, while Sokoto Gudali breed showed least susceptibility.
\end{abstract}

Keywords: Trypanosomosis, cattle, blood glucose, blood urea nitrogen.

\section{INTRODUCTION}

Blood glucose and blood urea nitrogen level in cattle has not been well researched in Nigeria. Hence, the Effect of Natural Trypanosomosis which has caused varieties of reported cases in cattle in subsaharan Africa was studied in Oyo, a South-western state in Nigeria, where there is high preponderance of tsetsefly, on the blood glucose and urea nitrogen levels.

\section{GLuCOSE SUPPLY}

The ruminant is in a disadvantageous position as compared to monogastric animals with regard to glucose supply, because only limited amounts of glucose and/or glucose polymers reach the intestine. Little escapes in ruminal fermentation and reaches the duodenum unchanged. The amount may vary widely, but seldom exceed $25 \%$ of that supplied. Another minor portion of feed carbohydrates will be transformed into microbial polysaccharides and may reach the duodenum as stored microbial carbohydrate. Most of the compounds undergo fermentation in the rumen and are hydrolysed into acetic, propionic and butyric acids.

The availability of glucose or its precursors depends primarily on the amount of glucose that is absorbed from the intestine and on the amount of propionic acids produced in the rumen (1)

\subsection{Implications of Increased Glucose Absorption}

In the early 1990's, an extensive review of published studies concluded that 'production studies provide no clear evidence that site of starch digestion enhances milk yield or changes composition' (2), suggesting no benefit of greater, or less, postruminal starch digestion. In contrast, other studies have suggested a benefit of increased ruminal starch digestion on milk and or milk protein yield (3), perhaps as a consequence of increased microbial protein supply. However, these conclusions were based largely on effects of steam flaking on corn or sorghum grains, which also improved total tract starch digestibility and increased ME supply. In early lactation dairy cows, incremental starch infusion into the abomasum at relatively low rates (up to $2 \mathrm{~kg} / \mathrm{d}$ ) increased milk yield, but decreased 
milk fat concentration in a quadratic manner such that there was little change in milk energy output except at the highest level of infusion (4).

\subsection{Glucose and Trypanosomosis}

Trypanosomes are avid feeders of blood glucose and they multiply rapidly and making the immune system of the animal compromised.

\subsection{Blood Urea Nitrogen (BUN) in Ruminants}

The level of blood urea nitrogen (BUN) have proven to be useful tools to monitor protein and energy nutrition of beef and dairy cattle under temperate conditions (5). However, up to date relatively little information is available on the relationship between this variable and the nutritional status of cattle fed on tropical forages. The knowledge of this relationship would allow the use of BUN as metabolic indicators of the protein and energy status of cattle and could be helpful in making nutritional management decisions (e.g. timing and level of protein supplementation). In pastures containing legumes high in tannins or BUN should be measured to estimate nitrogen availability in the rumen, Hess et al., 2000).

\subsection{Blood Urea Nitrogen and Trypanosomosis}

Trypanosomes have found to cause serious systemic dysfunction and kidney happened to one of the organs affected. It affects the glomerula filtration rate and hence reduces the performance of the animals (Robbin et al 1999).

\section{MATERIALS AND METHOD}

This study was carried out in three different locations in the south west of Nigeria namely;

- University of Ibadan (Veterinary Teaching Hospital)

- Ilora Cattle Farm (Elede Farm Settlement Area) and

- Oyo State Government Cattle Farm, Fashola, iseyin

The locations of these areas of study using Global Positioning System (GPS) from the University of Ibadan are -

- University of Ibadan is located at $7^{\circ} 45^{\prime}(\mathrm{N})$ and $3^{\circ} 89^{\prime}(\mathrm{E})$, on Oyo road, Ibadan.

- Ilora Cattle Farm is located $7^{\circ} 79^{\prime}(\mathrm{N})$ and $3^{\circ} 89^{\prime}(\mathrm{E})$, a distance of about $75 \mathrm{~km}$ from the University of Ibadan.

- Oyo State Government Farm, Fashola is located at $7^{\circ} 96^{\prime}(\mathrm{N})$ and $3^{\circ} 6^{\prime}$ (E) near Iseyin, a distance of about $85 \mathrm{~km}$ from the University of Ibadan. (6).

In this study, 136 cattle breeds was sampled comprising White Fulani, Sokoto Gudali, Red Bororo, Azawouk and their various crosses, to evaluate the effect of natural trypanosomosis on their blood glucose and blood urea nitrogen parameters. In situ blood glucose levels determination were done using glucometer and blood urea nitrogen levels were determined in the laboratory using BUN kit (Randox Laboratories, Uk). Hematological parameters were determined using standard laboratory procedures.

Jugular venipuncture, Mid- Coccygeal venipuncture, and Lateral saphenous venipuncture techniques were used to obtain blood samples from the live cattle on the field.

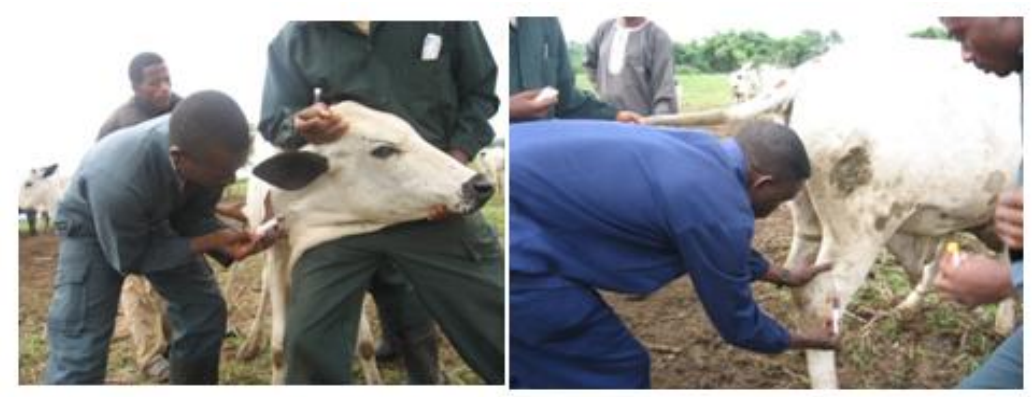

Some of the pictures taken during the field work 
Effects of Field Trypanosomosis on Blood Glucose and Urea Nitrogen Levels in Three Cattle Herds in Oyo State, Nigeria

\section{RESULTS}

White Fulani (WF) had 54 out of 117 sampled positive to Natural Tryanosomosis representing 46.15\% positivity, while Sokoto Gudali (SG) and their Crosses had all 11 sampled negative to Natural Trypanosomosis representing 100 negativity

Table1. Positivity and negativity of the breeds to natural Bovine Trypanosomosis

\begin{tabular}{|l|l|l|}
\hline \multicolumn{1}{|c|}{ Breeds } & \multicolumn{1}{c|}{ Positive } & Negative \\
\hline White Fulani & 54 & 63 \\
\hline Azawouk & 1 & 0 \\
\hline Red bororo & 3 & 0 \\
\hline Red bororo crosses & 1 & 4 \\
\hline Sokoto gudali & 0 & 3 \\
\hline Sokoto gudali crosses & 0 & 8 \\
\hline
\end{tabular}

The Mean Blood Glucose levels for the WF positive to trypanosomosis was the lowest with $(62.68 \pm$ 9.73) $\mathrm{mg} / \mathrm{dl}$ and SG which were $100 \%$ negative to trypanosomosis had the highest value of Mean Blood Glucose levels with $(75.25 \pm 20.47) \mathrm{mg} / \mathrm{dl}$. This was in consonance with John et al (1992) who stated that trypanosomes have preference for glucose in the blood.

Table2. Mean values of Glucose Parameters

\begin{tabular}{|l|l|}
\hline \multicolumn{1}{|c|}{ Breed } & \multicolumn{1}{c|}{ Mean Glucose \pm SD } \\
\hline White Fulani & $62.68 \pm 9.73$ \\
\hline Sokoto gudali & $75.25 \pm 20.47$ \\
\hline Sokoto gudali crosses & $55.67 \pm 7.92$ \\
\hline Red bororo & $70.5 \pm 6.36$ \\
\hline Red bororo crosses & $64.6 \pm 8.2$ \\
\hline
\end{tabular}

SG also had highest mean BUN value of $(1.92 \pm 0.40) \mathrm{mg} / \mathrm{dl}$, while WF and Red Bororo crosses had mean BUN values of $(1.59 \pm 0.49$ and $1.47 \pm 0.62) \mathrm{mg} / \mathrm{dl}$ respectively as the lowest obtained values.

Table3. Mean values of Blood Urea Nitrogen Parameters

\begin{tabular}{|l|l|}
\hline \multicolumn{1}{|c|}{ Breeds } & \multicolumn{1}{|c|}{ Mean Blood Urea Nitrogen \pm SD } \\
\hline White Fulani & $1.59 \pm 0.49$ \\
\hline Other breeds & $1.39 \pm 0.40$ \\
\hline
\end{tabular}

\section{CONCLUSION}

It was found that Trypanosomosis had great preference for blood glucose and keeping a trypanotolerant breed of cattle in South-western Nigeria will help combat this.

The Blood Urea Nitrogen was observed to be very low in all breeds sampled. (5) reported that for animals with BUN level lesser than $9 \mathrm{mg} / \mathrm{dl}$, additional protein supplement with help the animal grow faster. Therefore, animals in the South-western Nigeria should be given protein supplement as part of their diet.

N/B- normal range values for Blood glucose and Blood Urea Nitrogen levels are 42.1-74.5mg/dl and $7.8-24.6 \mathrm{mg} / \mathrm{dl}$ respectively.

\section{REFERENCES}

[1] Djokowoerjo sastradipradja. 1998, Glucose in Ruminants: A Review pg 59-65.ISSN 0854-8587.Vol. 5, No. 3. ULAS BALIK.

[2] Nocek, J.E. and S. Tamminga. 1991. Site of digestion of starch in the gastrointestinal tract of dairy cows and its effect on milk yield and composition. J. Dairy Sci. 74:3598-3629.

[3] Theurer, C. B. ,Huber, J. T. ; Delgado-Elorduy, A. ; Wanderley, R., 1999. Invited Review: Summary of Steam-Flaking Corn or Sorghum Grain for Lactating Dairy . J. Dairy Sci., 82: 1950-1959

[4] Reynolds, C.K., P.C. Aikman, B. Lupoli, D.J. Humphries and D.E. Beever. 2003. Splanchnic metabolism of dairy cows during the transition from late gestation through early lactation. J. Dairy Sci. 86:1201-1217. 
Effects of Field Trypanosomosis on Blood Glucose and Urea Nitrogen Levels in Three Cattle Herds in Oyo State, Nigeria

[5] Hammond A.L., Kunkle W.E., Gentio P.C., Moore S.A., Crossby C.E. and Ramsay K.H.,(1994): 'Use of Blood Urea Nitrogen Concentration to Determine Time and Level of Protein Supplementation in Wintering Cows". The Professional Animal Science 10: 24-31

[6] Google map Nigeria, 2010 www.nationsontmc.org/oneworld/map/google_map_nigeria, 2010.

Citation: Oladipo, T.A et al., "Effects of Field Trypanosomosis on Blood Glucose and Urea Nitrogen Levels in Three Cattle Herds in Oyo State, Nigeria", International Journal of Research Studies in Agricultural Sciences, vol. 4, no. 3, p. 8-11, 2018. http://dx.doi.org/10.20431/2454-6224.0403002

Copyright: (C) 2018 Authors. This is an open-access article distributed under the terms of the Creative Commons Attribution License, which permits unrestricted use, distribution, and reproduction in any medium, provided the original author and source are credited. 